\title{
Comunicação
}

\section{Marilene Leão Alves Bovi (1948 - 2006): uma vida de dedicação à pes- quisa com palmito}

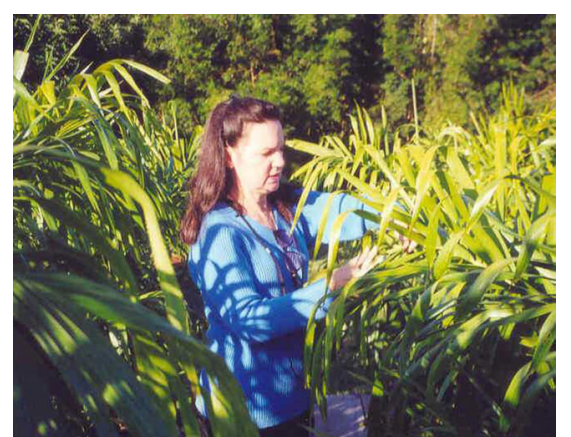

Marilene Leão Alves Bovi foi pesquisadora científica nível VI, do Instituto Agronômico em Campinas, atuando no Centro de Horticultura, em Campinas, SP. Estava entre as vítimas do acidente aéreo recém ocorrido no país

Formou-se em engenharia agronômica pela ESALQ/USP, em 1972, sendo $\mathrm{PhD}$ em Agronomia, com ênfase em Melhoramento Genético de Plantas, pela Florida University, Gainesville (USA), concluído em 1982. Atuava na área de melhoramento genético e fitotecnia de palmeiras produtoras de palmito.

Há 35 anos trabalhando no IAC, Marilene Bovi é referência nacional e internacional em sua área de atuação. Profunda conhecedora de palmito e com a visão de futuro e a perspicácia que caracterizam os grandes cientistas, foi pioneira no Brasil na pesquisa visando o cultivo da pupunha e a exploração racional do açaí e do palmito juçara. Com sua liderança, estabeleceu um amplo programa de estudos com palmeiras produtoras de palmito, com destaque para as linhas de melhoramento genético, fisiologia do crescimento e da produção, sistemas de cultivo, manejo sustentado e tecnologia de sementes, envolvendo grande números de colaboradores em todo o país. Os resultados de seus trabalhos contribuíram significativamente para o desenvolvimento sustentável das matas nativas, contribuindo para a sua preservação. Ao mesmo tempo, introduziu o plantio comercial de pupunha, transformando essa cultura em atividade competitiva no agronegócio da horticultura.

Recebeu seis prêmios em sua prolífica carreira científica, destacando-se o "Prêmio Frederico de Menezes Veiga", outorgado pela Embrapa em 2001, em reconhecimento à sua contribuição expressiva para a pesquisa com palmito.

Publicou 75 artigos em periódicos especializados e 159 trabalhos em anais de eventos. Possui 4 livros publicados, 18 capítulos de livros, além de outros 27 itens de produção técnica. Participou de 30 eventos no Brasil e exterior. Orientou quatro dissertações de mestrado, uma tese de doutorado e co-orientou duas teses de doutorado Também orientou um trabalho de conclusão de curso na área de agronomia. Entre 1998 e 2002 coordenou seis projetos de pesquisa, dois deles com financiamento externo. Atualmente, participava de sete projetos de pesquisa, coordenando seis deles. Em suas atividades profissionais interagiu com 146 colaboradores em coautorias de trabalhos científicos.

Foi uma grande incentivadora da criação do Curso Pós-Graduação em Agricultura Tropical e Subtropical, do IAC, onde tinha participação atuante no conselho do curso e, principalmente como orientadora, formando diversos profissionais. Por sua competência, foi escolhida pela CAPES para representar a PG-IAC naquele órgão.
Era assessora científica de agências de fomento, destacando-se FAPESP e CNPq, colaborava como revisora ad hoc dos mais importantes periódicos nacionais e como consultora em diversos programas brasileiros de pesquisa de pupunha. Participou de inúmeras bancas examinadoras de mestrado e doutorado em diversas instituições de pesquisa e ensino do país.

Marilene Bovi foi uma cientista de reconhecida competência em sua área de atuação e sempre teve uma participação destacada no âmbito da $\mathrm{ABH}$, participando ativamente dos CBO's e, atualmente, era uma das editoras científicas da Revista Horticultura Brasileira.

Marilene era séria e de personalidade forte, sempre exigente consigo mesma e com seus orientados e colaboradores, mas sensível o suficiente para respeitar os limites de cada um. Aberta e acessível com aqueles que queriam de fato pesquisar e aprender fazendo. Incentivava seus alunos e estagiários a estudar e adorava estar no campo junto aos seus experimentos. Era defensora da pesquisa regional, tanto que coordenava projetos com pupunha em diversos Pólos Regionais de Pesquisa localizados no litoral e no planalto do estado de São Paulo, onde considerava ser a cultura viável.

Apesar de cientista renomada, destacava-se pela discrição, simplicidade e pelo zelo familiar. Ela residia em Campinas (SP) e era casada há 32 anos com o também pesquisador do IAC, Odair Alves Bovi, com quem teve dois filhos.

(Arlete Marchi Tavares de Melo, Pesquisadora Científica, IAC-

APTA, Centro de Horticultura, Campinas, SP, e-mail: arlete@iac.sp.gov.br) 